\title{
Consistency, contradiction and ceaseless enquiry in the work of Michael Young
}

Guile, D., Lambert, D. and Reiss, M. J. (Eds)

This volume began as an idea that the three of us, as editors, had late in 2014, realising that 2017 would be the $50^{\text {th }}$ anniversary of Michael Young's arrival at the Institute of Education (now the UCL Institute of Education). In some senses the resulting volume is a Festschrift, from the German Fest 'festival' and Schrift 'writing', a Festschrift being defined as "a collection of writings forming a volume for presentation to a well-known scholar on the occasion of his attaining a certain age, pinnacle of his career, retirement, etc." (Dictionary of Collective Nouns and Group Terms, 2008). However, from the beginning we wanted the volume to be more than hagiography and, without discussing this with Michael, all three of us were sure he would want this too. As anyone who knows Michael will appreciate, one of the many great things about him is his willingness to discuss cheerfully, and often over a drink, almost any aspect of education. At the same time, such conversations have considerable rigour. All three of us can attest to the fact that some of the most intellectually demanding discussions we have ever had have been with Michael.

The book is divided into three sections. These are not hermetically sealed and it is possible to trace cross-cutting themes and a sense of unity between them - not least Young's enduring concern for the place of specialist knowledge in the school curriculum and in professional formation, more lately underpinned by social realism. However, the three sections provide a convenient and useful means to focus, and especially to draw out what we hope are new perspectives on Young's substantial contribution.

\section{Sociology}

As a discipline, sociology is usually said to have had its origins in $19^{\text {th }}$ century Europe. Somewhat ironically, given the subsequent reaction of most sociologists to positivism, the great positivist August Comte is generally identified as its founder. Comte, arguably also the first philosopher of science, and working in the aftermath of the shock of the French Revolution, saw sociology as a discipline that would grow once scientists understood biology better. His ideas were fertile ground for such other intellectual giants as Herbert Spencer, Marx and Durkheim. 
It is Durkheim who can also lay claim to being perhaps the first sociologist of education, and his work in this area remains influential to this day, not least to Michael Young himself. Durkheim's view of sociology as the science of institutions makes schools and other sites of education a clear focus of research, and early influences on Michael Young's work can be seen in Durkheim and in other educational sociologists such as Basil Bernstein, himself a former colleague of Michael's for many years at the Institute of Education.

As Geoff Whitty describes in his chapter, the 'old' sociology of education of the 1950s and 1960s was largely concerned with mapping social inequalities in education and exploring how the cultural features of working class homes and communities militated against children from such backgrounds succeeding in school (Craft, 1970). However, this meant that "relatively little attention was paid to the content of schooling itself". Along then came Michael Young's (1971) Knowledge and Control, once described to Michael Reiss by a former Chair of one of the Research Assessment Exercise (RAE) Education Sub-panels as 'the only edited book worth entering in the RAE'. This highly cited and controversial collection of essays on the importance of power in the determination of what counts as worthwhile school knowledge is often seen, especially by conservative commentators, as a past from which Michael Young has wisely retreated. But as Geoff Whitty points out, "Young's own commitment to relativisation, such as it was, might be viewed not as a statement of an epistemological position, but as a procedural device for subverting taken-for-granted assumptions about the seemingly absolute status of the knowledge which had come to be institutionalised in the school curriculum".

One of the features of Michael Young's academic life has been his fruitful collaborations with others. Nowhere is this greater the case than for the work he has done with Joe Muller. In his chapter in this volume, Muller highlights an important aspect of Michael's personality and working methods, one familiar to all who know him yet perhaps not generally recognised in the increasing number of written analyses of his work, namely "his irrepressible optimism that something better can and must be brought about, that defeats are only temporary, that victory may be delayed but is nonetheless on the horizon". It is this, Muller argues, along with "his unfailing generosity of intellectual spirit" that has contributed to the warm reception of his ideas, even from those who disagree with them. Muller instances how Michael reacted to Moore and Muller (1999) at first by writing in partial disagreement and then by co-authoring initially with the first author, Rob Moore (a wonderful sociologist of education, now, sadly, no longer alive), and then with the second, Joe Muller himself. Muller situates his chapter in a comparison of Michael Young's work with that of Peter Ramus (1515-1567) and Francis Bacon (1561-1626). He argues that Ramus was one of the first to discuss knowledge as a living tradition external to individual knowers and that Bacon constructed an artful blend of whiggish optimism about knowledge growth paired with an argument about the redemptive power of knowledge. Muller concludes that "Ramus, Bacon and Young all share a deeper attribute; they were all what Berlin (2013) 
called hedgehogs, scholars and writers who, despite dealing in details were always trying to refine the large binding idea that drove their intellectual energies and lifted their endeavours above those of their colleagues".

As befits the personal nature of a Festschrift, John Beck has produced a contribution that "is a double homage to two people who have been among the most important intellectual influences in my academic life: Michael Young and Charles Bailey". For those who do not know much about Charles Bailey, Beck's chapter is the place to start. Here, what is worth pointing out are the similarities between Knowledge and the Future School (Young et al, 2014) and Beyond the Present and the Particular (Bailey, 1984). A Beck puts it:

1) First, and perhaps most importantly, both set out and seek to justify a vision of a form of education that aims to liberate children and young people from the limited horizons of the present and the particular understandings available to them on the basis of their everyday experience.

2) Both accounts contend that giving learners access to a broad range of intrinsically valid and worthwhile knowledge is indispensable to such personal and cognitive liberation.

3) Both contend that an education of this kind should constitute the major part of compulsory state education;

4) an education which should be offered to the great majority of students, including most of those labelled 'non-academic';

5) throughout the years of compulsory schooling (5-16 in England).

6) Both accounts offer an ethical as well as an educational set of justifications for these proposals.

7) Both discuss a range of obstacles to realising this vision of education, focusing particularly on the challenges of economic instrumentalism and epistemological relativism.

8) Finally, both argue that a certain kind of professional autonomy is indispensable to realising the aims set out.

Given that sociology is a subject in the school curriculum, an interesting question arises about the extent to which it can be identified as a legitimate form of powerful knowledge. In their chapter, Antonia Kupfer and Hugh Lauder examine the British Sociological Association (BSA) and the Sociology School Curriculum in England. Using Lukes' (2005) conceptualisation of power, they conclude that the BSA controls not inconsiderable funds, undertakes a wide range of activities and has processes and outcomes that are not directly influenced by the state. With regards to A level Sociology, study of both textbooks and examination questions indicates, encouragingly, that students are being asked to think theoretically about social questions and that issues such as those of power and inequality are not marginalised. 
In her chapter Elizabeth Rata begins by noting that "The art of sociology is to make the familiar unfamiliar". Ambitiously, she attempts to connect Michael Young's work on knowledge with theorisations about democracy and concludes "that citizenship is only created in education systems which teach the abstracted and objectified knowledge found in academic subjects". Connecting curriculum and pedagogy, she points out that "How knowledge is taught depends upon what is taught". Furthermore, Rata argues that the ability to enact one's citizenship requires an ability to distance oneself from what one is considering so as objectify it and make predictions. This is precisely what Michael Young advocates in a curriculum based on durable, powerful knowledge rather than one based on constructivist principles of everyday experience. Such abilities are more likely to be acquired during one's schooling than at any other time. Rata then asks how it is that democratic principles (e.g., "equality, human rights, justice, and the peaceful arbitration of conflict") become internalised as part of a person's moral code. Again, the answer is seen as being found in the valuing of abstract as opposed to everyday knowledge: "A key to this question lies in the generalisable and predictive nature of abstract knowledge and the resulting potential for universability. The potential to connect imaginatively to people outside one's socio-historical experiences includes the potential to apply the same moral standards to all social groups; to universalise in other words".

While Michael Young is primarily a sociologist, much of his writing is philosophical, relying on arguments about epistemology and insisting on normative considerations. Jan Derry provides a philosopher of education's perspective on Michael Young's work. After siding with Michael Young against such identified opponents as Guy Claxton and Ken Robinson, Derry identifies what it is that is distinctive about both formal education and academic knowledge. As she puts it "For students, initiation into domains of knowledge creates the space for their concepts to be actualised in new ways". Derry's contention is that such initiation is what allow students to think systematically, to come to appreciate how particular ideas function and so to access their meaning. She aims to respond to what she sees as misconstrued readings of Young's work which take his emphasis on powerful knowledge to be at odds with a concern for pedagogy and human flourishing. Derry concludes that "The failure to recognise how knowledge has really developed in history, leaving students without access to 'powerful knowledge', ends up by serving the interests of the powerful more effectively than the propagation of ruling ideas could ever achieve".

Michael Young's work has had considerable international impact. In their chapter, Wen Wen and Weihe Xie examine the impacts of his curriculum theories on Chinese educational research and practices. These impacts have been considerable, in part because Michael Young's shifting accounts of the relative importance of constructivism and objectivity in school knowledge are mirroring (or anticipating) comparable debates in China. In particular, the recent translation into Chinese of Bringing Knowledge Back In, along with Michael 
Young's own well-attended visits to China, are helping to challenge the popularity of constructivism in Chinese curriculum studies. Wen Wen and Weihe Xie point out that "In China, the rationale for social constructivism becoming popular in education is that: it stimulates the innovation and creativity of individual teachers, it acknowledges the dominant status of teachers and students, it allows for social engagement in the curriculum, and it emphasises the subjectivity of practices in educational activities - all of which greatly challenges traditional Chinese education and sounds very attractive". However, the tide may now be turning and Michael Young is playing a role in this in no small measure because he avoids both traditional mechanical realism and relativistic accounts of knowledge.

\section{Curriculum Studies}

It is perhaps an understatement that "curriculum is a complicated concept" (Jung and Pinar $2016,29)$. From the classical origins of the idea in Europe to its export and the subsequent development of the field of curriculum studies in the USA during the twentieth century, its meaning has diversified and conceptions of curriculum have multiplied. Matters become even more complicated when we take account of national, cultural and historical contexts, making international comparisons and discussions notoriously difficult. We might note, therefore, that curriculum is not a form of 'powerful knowledge' - if universality is what we are after with that term. Indeed, Jung and Pinar have argued that "there can be no single or universal conception of curriculum, even when concepts seem to coincide terminologically" (ibid). And yet, as these authors also state, there are few more significant ideas in education. The editors of the monumental Sage Handbook of Curriculum, Pedagogy and Assessment do not shirk the implications of such a realisation: "We would even go so far as to say that curriculum (including pedagogy and assessment) is one of the defining areas of education as an academic discipline" (Wyse, Hayward and Pandya 2016, 10).

Michael Young might initially agree with most, if not all, of this but would probably wish to push things a bit. For example, he might not be happy with Wyse et al's explicit wish "to theorise the interconnections and inseparabilities of pedagogy and assessment" (op cit, 2) which explains the parenthetic qualification in their sentence quoted in the paragraph above. For Michael, the conceptual distinction between curriculum and pedagogy is very important indeed. This is because for him an unwillingness to separate curriculum questions from pedagogic matters risks undermining or weakening the key curriculum concern, of what to teach. The knowledge-led school is for Michael the answer to the question 'what are schools for?'. The knowledge-led curriculum is what makes schools special places. They have the task of inducting children into knowledge and knowledge making - and not just any old knowledge, but the best that we have (this claim places an enormous, and probably not widely acknowledged, responsibility on teachers). In this way young people may leave 
school with a rounded 'general education' (a description used by Tim Oates in his chapter) that has provided them with ... well, with what?

This is one area (the knowledge contents of a good, general education) where things get tricky. 'Knowing stuff' is clearly useful, and not just for Trivial Pursuits, but its use a signifier of being educated can be quite troubling - as in the case, for example, when Nick Gibb (as shadow schools minister before the installation of the 2010 Coalition government, and in thrall to E D Hirsch) confidently informed David Lambert that 11 year olds should 'know' the rivers of England (and the countries of Africa). Apart from the unsettling matter of a politician pontificating on the detailed contents of the curriculum, the incident illustrates one of the reasons why the Youngian notion of powerful knowledge is helpful and productive. It helps distinguish the educational role of knowledge in a way that a Hirschian list of core knowledge fails to do. The subtlety of Hirsch, and his concern for cultural literacy enabling social justice, is not always acknowledged. Even so, the superficiality of what is meant by 'knowing' Shakespeare, Pacific Ocean or any of the other 5000 or so facts that 'every American needs to know' (Hirsch, 1987) offers a less satisfactory view of a knowledge-led curriculum than one that explicitly asserts the socially produced status of knowledge and the role of specialist communities in arbitrating better knowledge. The Hirschian list appears given, predetermined and inert, the defining features of what Michael and Johan Muller (2010) called a Future 1 curriculum, whereas powerful knowledge, though reliable, is contested, dynamic and part of a system of thought which itself can change. The latter characterises Future 3: powerful knowledge is more systemic and requires entering the world of ideas and the human stories that lie behind their creation, as Michael Reiss indicates in his chapter (referring to Isaac Newton). If Hirschian core knowledge is roughly aligned with Future 1 curriculum thinking, and powerful knowledge (by definition) underpins Future 3 curriculum thinking, we have a useful heuristic that enables the role of specialist knowledge in education to be distinguished from the narrow concerns of cultural restorationists. However, as Tim Oates points out in his chapter, in comparison with outcomes-led approaches to curriculum, the differences between Futures 1 and 3 are not so great. The real 'villain' is Future 2, and Michael Young would agree with that.

In the end the acquisition of extensive, factual information and the intensive focus on how things work are not, of course, mutually exclusive. On the contrary, they are probably mutually dependent. And it is interesting to note that the retort provoked by Nick Gibb by his assertion about 'the rivers of England' ${ }^{1}$ some years ago could equally be asked of Michael Young. That is, what does 'knowing' mean in this context? What is it to know powerful scientific knowledge, and how is this different from practical everyday knowledge? The questions then keep coming: in the understandable quest to legitimise knowledge in curriculum thinking, partly through attacking the over-socialised pedagogic adventure that

\footnotetext{
1 The response was in fact how many rivers counted as 'knowing the rivers of England'. Had there been more time we might have also discussed whether memorising a list would do, or naming them of a map. And what would we need to know about the rivers? Etcetera.
} 
characterises Future 2, do we risk sideling pedagogy and (inadvertently) undervaluing situated, contextualised practical knowledge and/or ways of knowing? Thus, in his chapter, David Scott opens up a philosophical discussion which includes looking at the relationship between propositional, scientific and practical, everyday knowledge, including (he argues) taking account of the 'pedagogical' components in each form. The distinctions between powerful knowledge (acquired through school) and everyday knowledge, he concludes, are perhaps less stark, or more readily bridged, than might first appear when we focus exclusively on what the specialised, disciplinary knowledge component is - as a product, as it were. "We have to understand how knowledge is and can be constructed" Scott writes, stressing perhaps the key contrast between Future 1 and Future 3 ways of conceptualising the curriculum.

In their different ways Michael Reiss, Lyn Yates and David Lambert also explore theoretical questions such as these in their chapters. Each of these chapters acknowledges the contribution Michael Young has made to their own work: Reiss, through his collaboration with John White (and conscious of course of the long-running conversation between Young and White about the purpose of schools and the aims of education) and his work as a science educationist; Yates through her emergence as a curriculum scholar and her longstanding concern for equality and social justice, especially in terms of gender; and Lambert through his role as a geography educationist which included a stint leading the Geographical Association which brought him into lobbying activities and policy discussions about curriculum form - and function. Taking a point that Lyn Yates develops more fully in her chapter, Michael Young has, rather like David Scott in this volume, spent many years 'standing outside' the day-to-day challenges that face educators, crucially providing "new ways of seeing curriculum, knowledge and social forms". These chapters show how these outsider perspectives have been taken up in the respective specialist fields, frequently with some difficulty, but always constructively. Tim Oates explains this in terms of the fundamental and consistent, progressive strand in Young's work - which does not lie in the simple, banal claim that knowledge is important. It lies in identifying the 'separate authority' that is associated with the disciplines. David Scott might not agree with this, but it is an important claim to make to government ministers who may be tempted to meddle with the history curriculum, for example, or invent new subjects to meet political expediency. It is also a vital point to make to policy makers tempted to reduce teacher education and training to the matter of achieving technical competence.

John Morgan in his chapter, like Lyn Yates and Tim Oates in theirs, focusses on the consistently progressive tone to Michael's work as he has forced the question: what exactly is the knowledge to be taught in schools? The question has not yet been fully answered. For one thing, appealing to the disciplines-as-authority is not enough because, as Lambert and Reiss point out in their chapters, there is no easy pathway to the recontextualisation of discipline to school subject. But Morgan introduces another, more fundamental issue which 
was alluded to by Ken Jones in his otherwise generally positive review of Young and Lambert (2014). Jones discussed the recontextualising point and indeed other questions pursued by several authors in this volume about the "thickest of lines" Michael has tended to draw between scientific knowledge and everyday knowledge. But he also suggested that Michael's exploration of curriculum could be seen as a little too 'pure' - eschewing issues of performativity, accountability, assessment and the degree of teacher autonomy that exists today (or indeed in the past). What Morgan does is analyse Michael's work, from Knowledge and Control to the present day, through the lens of capitalism and its successive crises. Thus, we learn that Future 2 type knowledge is supportive of modern, fast capital: "it favours individualisation, personalisation, flexibility and consumption rather than the more traditional Future 1 type knowledge". In this analysis, Future 3 may be seen as a progressive alternative, but one with little chance of taking hold unless teachers - and their leaders see the educational limitations and the social iniquities in Future 2.

And thus we can see glimpses of both Michael's hugely distinctive contributions to curriculum debates, and at the same time several ways in which these constitute work in progress. There is no question that Michael's curiosity and sharp focus on curriculum matters has had enormous influence and impact as all the authors in this section testify in different ways. However, what these authors also do is decline any temptation to set aside their critical faculties and simply celebrate Michael's contributions. There is more work to be done.

\section{Professional and Vocational Education}

Historically, professional and vocational education have been conceived of as separate and different from one another by writers in most advanced industrial counties. People who write about professional education tend to maintain there is an epistemological basis to certain occupations which requires study in a university prior to qualification, as, for example, in engineering, medicine and law (Abbott, 1988; Freidson, 2001), whereas people who write about vocational education do not, in the main, make a comparable argument about the epistemological basis of occupations deemed vocational, as, for example, Agriculture and Construction (e.g. Electrical, Plumbing, Carpentry) (Deitmar et al. 2015; Pilz, 2012).

What this split between the professions and vocations has always tended to play down, however, is that they are both concerned with the theory-practice relation. Stated another way, the relation between disciplinary knowledge and practice is as central to professional as much as vocational formation. We can see this from a cursory glance at the literature on apprenticeship in European counties (Deitmar et al. 2015; Fuller \& Unwin, 2012; Pilz, 2012; Rauner \& Smith, 2010), and the literature on professional formation (Eraut, 1994; Higgs \& Titchen, 2001). The primary reason for this, all too often, unacknowledged common concern 
for the theory-practice relation is that the formation of professional and vocational expertise (and by extension, identity) presupposes enculturation in occupational practice in workplaces, and such enculturation presupposes, in turn, a knowledge base that new entrants learn through study in higher or further education or through self-directed learning. Whilst the length of study to acquire a degree and licence to practice for occupations deemed professional tends to be longer than for an occupation deemed vocational, this difference is mainly an issue of regulation through the influence of professional bodies rather than the absence of a knowledge base.

For the above reason, Michael Young's work on vocational and professional knowledge is a rare example of someone who appreciates the role that disciplinary knowledge plays in professional and vocational formation. To address this common issue, he draws on both of Bernstein's (2000) 'knowledge' lexicons: 'vertical' and 'horizontal' knowledge structures and 'singulars', 'regions' and 'generics', using the former to discuss the part that disciplinary knowledge should play in vocational formation and the latter to distinguish between the part that different types of disciplinary knowledge plays in professional formation. Despite never explaining the reason for employing different lexicons to address the role of disciplinary knowledge in vocational and professional education, Michael makes a broadly similar argument, which can be summarised as: professional and vocational education provide learners with knowledge they subsequently apply in a field of practice.

The contributors to this section of the book also do not remark on Michael's different lexicon and focus, instead, albeit in very different ways, focusing on Michael's argument about the part knowledge plays in professional and vocational formation, and his relative silence about the contribution that contextual factors, for example, institutions, labour market, organisation of work, make to this process. Three different responses can be discerned: the supportive-extension; the critical; and an alternative vision of the purpose of the theorypractice relationship.

Stephanie Allais, Jeanne Gamble and Leesa Wheelahan's chapters represent the first position. Allais and Gamble locate Michael's influence on vocational education (subsequently, Technical and Vocational Education and Training (TVET)) in South Africa by acknowledging that in the post-apartheid context the notion of a national qualifications framework (NQF) based on a system of learning outcomes for credits achieved was widely seen as a starting point for democratising relation between education and work. They then note that Michael, when he visited South Africa in the mid 1990s, brought an educational critique of standards, outcomes and credits based on his differentiation between everyday and disciplinary-based domains of knowledge and between teaching and learning, which foreshadowed problems South Africa would face with its NQF framework. They both acknowledge, though in different ways, that Michael's abiding legacy in the South African education policy domain was his unwavering and inclusive insistence that knowledge matters in qualifications, in curriculum, 
and in pedagogy; in all forms of academic and professional education but equally so in the vocational domain.

Starting her chapter from the premise that disciplinary knowledge is the basis of all formal education (academic and vocational), Stephanie Allais pays tribute to the force of Michael's educational critique of learning outcomes and NQFs to set the scene for her discussion of the limitations of his's concept of 'powerful knowledge'. Allais deepens our understanding of challenges associated the attempt in South Africa to overhaul the skill formation system by acknowledging that, despite being widely supported dissatisfaction soon set in with the idea of learning outcomes, and that Michael's defence of knowledge rather than outcomes as the basis of all curricula has been crucial to her own analysis of why an over-reliance on learning outcomes and qualifications in the reform of education is misguided. The complexity of technical and vocational education in South Africa is, as Allais highlights, such that an emphasis on powerful knowledge, by itself, is unlikely to assist in resolving the problems of the vocational curriculum. She argues that vocational curricula are influenced in South Africa, and by extension other countries, by contextual factors, such as the economic and social and labour market context - and that these factors bring to the fore issues about the relationship between power and knowledge. To gain further insight into how to improve curricula and strengthen the role of knowledge in vocational curricula requires, Allais concludes, addressing the way in which power plays out in the economy, labour market etc.

Leesa Wheelahan also starts from a similar premise. She acknowledges that Michael's analysis of vocational education, via Bernstein's distinctions between vertical and horizontal knowledge structures, led him to question the role of knowledge in education in general and to develop his influential argument that the raison d'être of education, including vocational education, should be to provide students with access to theoretical knowledge. Building on Michael's analysis of learning outcomes, competency-based training and the policy frameworks that accompany these developments as measures that systematically deny students access to knowledge, Wheelahan demonstrates the devastating effect their introduction has had on the public provider of vocational education, technical and further education (TAFE) institutes in Australia. She concludes that this has occurred because successive Australian governments have based the reform of TAFE on the principle of relevance and hybridity, which have underpinned global arguments about the purpose of vocational education, rather than employing the principle of insularity to provide students with access to the boundaries between different kinds of knowledge, and using their understanding of disciplinary boundaries as the basis for making connection between different forms of knowledge. Wheelahan draws on literature associated with 'new institutionalism', which is not usually associated with the form of social realist scholarship Michael advocates, to extend his argument about how vocational education can provide access to knowledge. She argues that the principle of insularity also needs to be applied to demonstrate why public vocational education colleges, rather than private training 
organisations, are the institutional enabling mechanism necessary for the codification, elaboration and institutionalisation of knowledge and skills needed for work, not now, but in the future.

Jeanne Gamble extends Michael's theoretical engagement with the notion of vocational knowledge, using his paper Conceptualising vocational knowledge: some theoretical considerations, which was included in a South African volume they co-edited, as a starting point (Young \& Gamble, 2006). The book brings together different critiques of NQFs and competence as curriculum basis in South Africa, and serves as an early legacy of Michael's scholarly influence and collegiality in encouraging and facilitating South African researchers' entry into international fields of scholarship and research in the sociology of education. In this chapter Michael and Jeanne both draw on the sociologist Basil Bernstein's work, albeit in different ways, to construct alternative conceptions of the theory-practice relation in vocational education. Gamble argues that Michael's sociological reading should be understood as constructing the 'high road' of vocational education and training (VET) within a traditional liberal education perspective that invokes earlier traditions of mathematics and science-based instruction as the basis of technical education. Her reading retrieves crafts and trades as early prototypes of vocational education and leads theoretically to a 'middle road' in vocational curriculum terms. The 'middle' road, which does not start with formal knowledge encoded in a subject discipline curriculum in either pure or applied form, refers to specialised knowledge transmitted in and through practice. The two interpretations are at odds in their respective positions on the recontextualising logic of the vocational curriculum and what this means for 'practice' as a curriculum component but they stand in a complementary relation in their opposition to the 'low road' of standards-based curriculum prescriptions. The overall argument is that ongoing theorisation would need to take account of both these 'knowledge' arguments, to deepen possibilities in relation to both the 'theory' and practice' dimensions of curricula that prepare for work and to ensure that technical and vocational education (TVET), as a study option, does not preclude rather than include.

In contrast, David Guile argues that Michael has in his own writing and in his work with Johan Muller about the professions over-stretched his 'knowledge' argument in three main ways. They are: (i) maintaining that entry to all professions is via the study of a degree that has a close relation to a field of practice when this relationship only applies to a limited number of professions; (ii) glossing over the constitutive role of work in the development of professional expertise in ways that render the term 'field of practice' deeply problematic; and (iii) relinquishing his earlier concern in The Curriculum of the Future (Young, 1988) to consider the implications that changes in work, especially technological changes, may have for the design and delivery of professional education. This leads Guile to conclude that there is, in Michael's work, in the $21^{\text {st }}$ century a slightly nostalgic flavour about, and overly restricted analysis of, knowledge and the professions, especially when compared to the challenges that a number of writers have recently suggested lie waiting in store for the professions and their particular 
forms of specialisation, for example, to be replaced by robots (Ford, 2015; Susskind \& Susskind, 2015) or to work in reduced numbers with robots (Brynjolfson \& McAfee, 2012) where the term robot is used as a shorthand for Artificial Intelligence.

Guile argues that by, firstly, adhering to Durkheim's legacy rather than the spirit of his sociological inquiry, Michael has been overly faithful to Bernstein's knowledge lexicon when considering the relationship between knowledge and the professions. Secondly, in overlooking the emergence of 'immaterial' labour associated with the new 'cognitive' division of labour (Moulier Boutang, 2011) he has paid scant regard to what the chapter refers to as interprofessional tacit knowledge which constitutes the knowledge-in-use in the aforementioned division of labour. Michael therefore lacks a lexicon to describe the forms of knowledge professionals produce in intra-and inter-professional groupings at work and the way in which this resource, which is embedded in technology (i.e. software design) and accessed through technology (i.e. digital repositories), as well as embodied in individuals' professional practice, can be shared and, in the process, support professional formation. Guile concludes by outlining a recontextualised (i.e. Cultural-Historical rather than Bernstein-based) model of professional formation which, unlike the trinary, presents a role for all forms of knowledge as constitutive elements in professional formation and supports the development of forms of professional practice commensurate with the challenges associated with immaterial labour.

In his chapter, Ken Spours introduces a conception of the theory-practice relationship that rarely surfaces in debates about such issues and, in the process, develops a hybrid of the preceding interpretations of Michael's work on vocational and professional education. Starting with Michael's most recent argument about specialization and the role of universities and schools in the production and mediation of specialist knowledge in defining the purposes of education, Spours gives Michael's Durkheimian and Bernsteinian perspective a Gramscian twist. Discussing the strengths and limitation of two versions of the general intellect - classical Marxist Techno-Economic and Liberal Rationalist - in relation to Gramsci's theory of politics and concepts of hegemony, historical bloc and common sense/good sense in the conditions of 'New Times', Spours articulates a third version - the 'Organic Intellect'. In other words, someone who is committed to using the interface between theory and practice as a resource to address the global and national socio-economic challenges of the $21^{\text {st }}$ century. He then uses this multi-dimensional concept to reflect on Michael's approach to specialization and the curriculum of the future, arguing that earlier aspects of his work on 'connective specialization' (Young, 1998) hold as much promise as his recent theories of the role of knowledge in education in the attainment of Futures 3; that is, a curriculum predicated on boundary maintaining and boundary crossing. Spours' chapter concludes by suggesting that Michael should consider six conceptual movements related to his most recent work on knowledge to take his work beyond a defence of the disciplines to engage with the 'new radical horizontalities' in $21^{\text {st }}$ century advanced industrial societies. These progressions could, 
according to Spours, constitute a prospective 'Fourth Period' for Michael which he could apply creatively not only to secondary education, but also to professional and political life more broadly.

The above responses to Michael's work may appear, at first sight, to be in conflict with or diverging from one another; they are, however, closely related since each writer is highlighting different limitations of, while recognising the value of, Michael's knowledge argument. They are all encouraging him to develop a further phase of work and have suggested four different ways of doing so. These are to explore: the institutional conditions for the teaching of knowledge; the criteria to underpin a knowledge-practice curriculum; the relationship between post-disciplinary development of knowledge in workplaces and disciplinary knowledge; and the development of organic intellectuals.

\section{References}

Abbott, A. (1988) The System of the Professions: An essay on the Divisions of Expert Labour. Chicago: University of Chicago Press.

Bailey, C. H. (1984) Beyond the Present and the Particular: A theory of liberal education. London: Routledge and Kegan Paul.

Berlin, I. (1953/2013) The Hedgehog and the Fox: An essay on Tolstoy's view of history. Princeton: Princeton University Press.

Bernstein, B. (2000) Pedagogy, Symbolic Control and Identity: Theory, Research and Critique (Revised Edition). Lanham: Rowman and Littlefield.

Craft, M. (1970) Family, Class and Education: A reader. London: Longman.

Deitmar, L. Hauschildt, U. Rauner, F. \& Zelloth, H. (Eds) (2015) The Architecture of Innovative Apprenticeship. Dordrecht: Springer.

Dictionary of Collective Nouns and Group Terms (2008), The Gale Group. Accessed from http://www.thefreedictionary.com/festschrift.

Eraut, M. (1994) Developing Professional Knowledge and Competence. London: Falmer Press. Freidson, E. (2001) Professionalism: The Third Logic. Cambridge: Polity Press.

Ford, M. (2015) The Rise of the Robots: Technology and the Threat of Mass Unemployment. New York: Basic Books.

Fuller, A. \& Unwin, L. (2012) Contemporary Apprenticeship. London: Taylor \& Francis.

Higgs, J. \& Titchen, A. (2001) Practice Knowledge and Expertise in Health Professions. Oxford: Butterworth-Heinemann.

Hirsch, E. D. (1987) Cultural Literacy: What every American needs to know. New York: Houghton Mifflin. 
Jones, K. (2015) Review Essay: Knowledge politics, British Journal of Sociology of Education, 36(3), 495-504.

Jung, J-H. \& Pinar, W. F (2016) Conceptions of Curriculum. In Wyse, D., Hayward, L. \& Pandya, J. (Eds) The Sage Handbook of Curriculum, Pedagogy and Assessment. London: Sage.

Lukes, S., (2005) Power: A Radical view, 2nd edn. Basingstoke: Palgrave Macmillan.

Moore, R. \& Muller, J. (1999) The discourse of 'voice' and the problem of knowledge and identity in the sociology of education, British Journal of the Sociology of Education, 20, 189-206.

Moulier Boutang, Y. (2011) Cognitive Capitalism. Cambridge: Polity Press.

Pilz, M. (2012) (Ed.) The Future of Vocational Education and Training in a Changing World. Dordrecht: Springer.

Rauner, F. \& Smith, E. (2010) Rediscovering Apprenticeship. Research Findings of the International Network on Innovative Apprenticeship (INAP). Dordrecht: Springer.

Susskind, P. \& Susskind, R. (2015) The Future of the Professions: How Technology Will Transform the Work of Human Experts. Oxford: Oxford University Press.

Wyse, D., Hayward, L. \& Pandya, J. (Eds) (2016) The Sage Handbook of Curriculum, Pedagogy and Assessment. London: Sage.

Young, M. (Ed.) (1971) Knowledge and Control: New directions for the sociology of education. London: Collier-Macmillan.

Young, M. (1988) The Curriculum of the Future. London: Taylor \& Francis.

Young, M. (2006) Conceptualising vocational knowledge: some theoretical considerations. In M. Young \& J. Gamble (Eds) Knowledge, curriculum and qualifications for South African further education Cape Town: HSRC Press.104 - 124.

Young, M. \& Gamble, J. (2006) (Eds) Knowledge, curriculum and qualifications for South African further education. Cape Town: HSRC Press.

Young, M. \& Muller, J. (2010) Three educational scenarios for the future: lessons from the sociology of knowledge, European Journal of Education, 45, 1: 11-27.

Young, M. F. D. \& Lambert, D. with Roberts, C. and Roberts, M. (2014) Knowledge and the Future School: Curriculum and Social Justice. London: Bloomsbury. 